SHS Web of Conferences 6, 01011 (2014)

DOI: $10.1051 /$ shsconf / 20140601011

C Owned by the authors, published by EDP Sciences, 2014

\title{
The Predicament and Outlet of the Rule of Law in Rural Areas
}

\author{
Yao Tianchong ${ }^{1}$, Song Chen ${ }^{2}$ \\ ${ }^{1}$ School of Humanities \& Law, Northeastern University, 110004 Shenyang Liaoning, China. \\ ${ }^{2}$ School of Humanities \& Law, Northeastern University, 110004 Shenyang Liaoning, China.
}

\begin{abstract}
The slowing and backward situation of China's current rural legalization construction has not aroused our attention and seriously effects the construction and development in the country. The legalization requires us to explore new ways to solve the predicaments in the rural areas, first farmers' rights conscious should be strengthened, reform of democratic system in the country need to be deepened, the law concerning land contract law need to be modified, and the law need to be popularized in the country so that law construction can be perfected in the rural areas.
\end{abstract}

Keywords. the rule of law in rural areas; predicament; outlet; harmonious

\section{Introduction}

Building new socialist countryside, the construction of political and economy in rural areas is exactly important, but the construction of the rule of law in rural areas is also indispensable. The rule of law in rural areas is an important part of Chinese law. But with the problems in agriculture, rural areas and farmers being more prominent and production of a series of problems in the process of building a new socialist countryside, the rule of law in rural areas has become an obstacle in China law. Given the basis of the integrity and diversity of rural society, to explore the modern way of the rule of law in rural areas and find out the effective strategy.

\section{Overview of rule of law in rural areas}

\subsection{The concept of rule of law in rural areas}

For the concept of rule of law in rural areas, there are two different viewpoints in academic circle. The first view is that "the so-called rural the rule of law, refers to the maintenance under the premise of national unity under the rule of law, make full use of legal means to manage rural activities, in order to ensure the sustainable development of agricultural economy and the legitimate interests of the broad masses of farmers, and to provide powerful legal safeguard the socialist rule of law of subsystems for the rural reform, development and stability." The second kind of view is that the rule of law in the rural area is on the basis of positive interaction between the national law and folk law, in order to realize the villagers' autonomy as the core, to cultivate farmers' concept of democracy, equality and freedom as the goal, to create a public mechanism to ensure the basic rights of farmers for key government propulsion power and social evolution of organic unity.

The above two different points of view are biased in nature and purpose. The author believes that the rule of law in rural areas is to govern the rural affairs under the law which reflect the will of the 
people and the social economic law and the natural law laws; the rule of law in rural areas is put all activities of the subject of the rural society into a unified, fairness and justice standardized track of the legal system.

\subsection{The nature of rule of law in rural areas}

The construction of rule of law is an arduous historical task, and it must be carried out simultaneously. Through the analysis of the concept of the rule of nature, we can summary seven aspects as following: (1) the rule of law in rural areas is a kind of governance strategy to manage rural political, economic, cultural and other affairs according to the law ; (2) the rule of law in rural areas is a rational principle, namely "according to law", especially the rural administration according to law is more important; (3) the rule of law in rural areas is a kind of legal mode beside on democracy

\subsection{The realistic significance of rule of law in rural areas}

Party's 16 session of fifth plenary session proposed the construction socialism new countryside as a goal, then it pushed the problem of countryside to the unprecedented height, so the rule of law will inevitably become the strategic choice for China's ruato to ensure the realization of these goals. The construction of the rule of law of reality is of great significance, meaning can be summed up in a five. (1) the rule of law in rural areas is an urgent need for the construction of new socialist countryside; (2) It is an important measure to accelerate the process to realize the rule of law in rural areas and to be agricultural modernization; (3) to realize the rule of law in rural areas is the inevitable choice to implement a rural agricultural macro-control under the condition of socialist market economy. So we regulate rural politics, economy and society by law, which cannot be effected by the personal factors. Therefore, carrying out the rule of law in rural areas is particularly important.

\section{Realistic predicament of rule of law in rural areas}

\subsection{The subject of the rule of law in rural areas is not intact}

The subject under the rule of law is the premise that we must solve in the theory and practice to realize the rule of law. In a democratic country, the subject can only be people. In our country, the subject can only be broad masses of people, in the countryside, farmers. The shortage in farmers has become an important factor to hinder the development of the rule of law in rural areas.

Since China's reform and opening up, Chinese farmers' legal consciousness enhancement and improvement of economic development level did not form direct proportion relationship. Along with the growth of the economy and speed up the pace of China's legislation some areas farmers' legal consciousness do not obviously, for example, farmers adoring the power, the fuzzy about rights and obligations, the indifference in subject consciousness and the lack of legal knowledge, etc. During the process of the rule of law, the legal knowledge people know, not only affect the legal safeguard of their rights, but also affect their compliance with the law. Farmers know few rights they have; in their mind obligations is the core, rights is secondary. The concept about power is greater than the law "is an indelible shadow in a farmer's heart. They often think they need "relationship", "money" and "power", but they do not need law. They think law is a external thing, because they can not even feel the power of the rule of law.

\subsection{The rural democratic politics is not perfect}

First of all, difficult to change the thought idea, the poorly organized by the government at the grassroots level. Because since the ancient times our countryside is a great shortage of the idea and consciousness of democracy and legality, the feudal traditional factors influence deeply. Thus these have caused many adverse effects to modern democratic rule of law. Some grass-roots organizations 
do not do practical things, and not understand the public opinion, and stay away from the masses and loss of morale, bureaucracy, corruption and so on, so that the relationship between the government and people is intensified, even cause masses riots, harming the social security. Secondly, the rule of law also requires the judicial rule of law, administrative law and the perfect supervision system, but these are the things the countryside in China lack of. Our grass-roots courts in our country are set up in the country level, the money lacks, whose finance comes from the local government. All of these will affect the independence and impartiality of the trial court. Thirdly, the administrative organ and rural life contact more closely, if administrative organs cannot do administration according to law, it will cause people suspecting of organs of state power, and influence the evaluation to the law, and it will make the growth of the rural culture of law constantly influenced by other factors, led to it into the predicament.

\subsection{The countryside land contracting management system is not perfect}

China's current rural land contract law clearly stipulates: "Right to the contracted management of land made from contract with the family and other forms can legally take subcontract, lease, exchange, transfer or by other means of circulation." This ear set for farmers, provides legal protection to the contracted management of land. But in the process of its actual operation there are some problems. On the one hand, the right can be easily violated in the land circulation. On the other hand, the right to the contracted management of land transferring procedures and the content is illegal. Besides, in accordance with the provisions of the contract law the period for cultivated land is 30 years. But some worked out by the party of the contract, there is no contract stipulated time inside, the contactor don't care about this, forcing farmers to lack of land earnings expectations.

\section{The influence of rural plight of the rule of law}

\subsection{Rural economic lag influence on the rule of law}

Economic base determines the superstructure, which is known as the philosophy theory, so a lot of people think the development of the rule of law in rural areas is the most important thing is to rely on the development of its economy, or it will become empty talk. The author thinks that this kind of idea is right, and we all cannot leave realistic condition to talk about theory, even if theory is very good, it is useless because it can't practice and society .So to develop the rule of law in the countryside, the first is for rural economic development. We all known, the problem of agriculture, rural areas and farmers in our country has a long history, many of the rural problems have not found the solution of the substance. The concentration and distribution of agricultural resources, that is, the problem of rural market economy is still at a very backward stage. So the author thinks that the state and the government should be more efforts in this respect, the overall planning for rural economic development mode, to regulate the rural economy market, efforts to improve rural living standards and education levels. In this way can we really solve the problem. To the rural market, the government must carry on the effective know, but this is not to interfere in, we can only legitimate and reasonable guide, but cannot be forced. In all our purpose is to develop the rural economy and the rule of law better, improve farmers' rights consciousness and legal meaning, let them better to safeguard their own rights and interests, this also is to build a new socialist countryside.

\subsection{The rural autonomous mode's influence on the rule of law}

In our country "Rural Villagers Committee" is a sign of political democracy. The law provides legal protection for a lot of problems in the countryside, for example, democratic decision-making, democratic management in accordance with the village. At the grassroots level, farmers can according to his intention elect the people of the villagers' autonomous organization, and the principle of democratic centralism is in the good practice, and the real service to everyone. And of course, we also 
want to see, although we have made a lot of good results, because the rule of law is not can be done overnight, and many of the objective conditions also hindered the development of better, so in reality we still have a lot of shortcomings. First of all, the villagers of democratic autonomy initiative and enthusiasm are not enough. Secondly, villagers' committee in unclear legal status, and the relationship between the villagers committees and the grass-roots government need clear rules. Finally, the consciousness of villagers' committees and the democratic decision needs to be further improvement.

\subsection{The popularizing-law work slowly influence on the rule of law in the countryside}

In the last four of the five years popularizing-law preaching work, although we have made good progress, there are still some shortcomings. Displays in: first, the popularizing-law preaching of content is on the lack of pertinence, the mastery of the knowledge of farmers' legal status is not very clear, the farmers' legal knowledge and moist please hold no, not very well for some laws and regulations related to farmers' vital interests effectively preaching. Secondly, the way of the popularizing-law is single. With the "force-feeding" rule of law should be the education is given priority to, method of the word is too professional, legal theory is too abstract, did not notice the ability of the farmers' acception, directly affects the farmers' concept of the rule of law culture. Third, the popularizing-law work ignored the need to quickly improve the quality of rural cadres law. In fact, in the countryside, the village cadres to a great extent, use the power. They can handle affairs according to law, they can resolve the dispute in accordance with the law, have a great education demonstration effect. So for the exercise of the rural power without effective legal training, it will bring many unfavorable consequences.

\section{A way out of the rule of law in rural areas}

\subsection{Strengthen the awareness of farmers' right standard}

In order to fully protect farmers' rights, must let them to establish the idea of right standard. The basic spirit of the rule of law is to respect human rights which treat people not the so-called rule of law is not the real rule of law. Therefore, first of all, we should fully respect the farmer's private rights. Currently in the process of the rule of law in rural areas, farmers' rights more is done by the way of administrative, which makes the government or its staff in the process of practice easily damage the interests of farmers because of neglect or dereliction of duty, even the rural deserves some interest as a government for its reward and grace, thus effectively. Secondly, to eliminate the consciousness of law are tools. The planned economy era, the law is used to control and regulate the people's government. So for a long time people mentioned that the law will not think of it also protect their own interests, thought that the law only control oneself, oneself should obey the law only, bur they has not thought of the legal services for themselves. This thought of laws is only tools of rule seriously hindered the further understanding of the law. Finally, we must strengthen the farmers' procedural rights. From a point of view, the law can be divided into two parts of the substantive law and procedural law.

\subsection{Deepen the reform of the system of rural democratic autonomy}

In the process of construction of new socialist countryside, we should increase the interest of the society as a whole and realize social essence fair perspective, as the main body of new countryside construction as reasonable allocation of rights and obligations. Radically changing the farmers is the understanding of the object in accordance with the law to promote agriculture, building up the idea that the peasant is the theme of the rule of law in rural areas to truly from theory and practice to realize standardization, legalization and institutionalization of the affairs of the new countryside. Democracy at the grassroots level and self-governing directly affect the masses of development and 
improvement of the relationship and the rural stability and development, affect the local rule of the process of modernization in the countryside.

\subsection{Modify the rural land contracting law}

First, it is strictly prohibited rural contracted land pastureland. Expressly provide the contractor shall not be pastureland, this makes the rural land contracting law consistent with the provisions of the land administration law, also can be in accordance with the law stipulate in the contract the contractor shall not be pastureland, continuous pastureland for two years, by the party to recover the pastureland of arable land; second the increase of the recovery of the ground conditions. The author suggested that contract period inside, contractor's family move to towns, and urban residents enjoy social security, it shall be returned to the party contracting farmland and grassland. The contractor does not return, while the party can take back the contracted land and grassland; third, the peasants should be included in the adjustment of the villagers' autonomy. The farmer has a long and guaranteed land-use rights, the ultimate goal is to make farmers more fully, effective and rational use of land, so as to safeguard and promote the development of agriculture and the rural economy and rural social stability. The law article 5 and give farmers contracted land the collective economic organizations in accordance with the law, and regulations, any organization or individual shall not be deprived or illegal restriction of rural collective economic organizations to members of the contracted land rights.

\subsection{Strengthen the popularizing-law work in the countryside}

An important influence on the effectiveness of the factors of the new countryside under the rule of law is the rule of law environment. Strengthening legal services and theoretical study, carrying out the legal knowledge popularization education and strengthening the administrative law enforcement and judicial work are to build new rural environment of rule of law, and are the main steps of build new atmosphere. Law popularization propaganda education is not only the expansion of rural society and update the process of legal knowledge, but also a response to local rules and order state propaganda of knowledge to form new social rules under the rule of law and order in the process. To choose the way of the farmers are relatively easy and lovely to accept, laminating the general farmer populace's demand for legal knowledge and the cultural habits of thinking, make peasants easily can learn new legal knowledge, enhance legal consciousness in the fun, through the way such as broadcast television newspaper, constantly create a strong atmosphere of the rule of law; We have organised by organizing volunteers to participate in the activities of our rural legal publicity and education, through more instill the law in the form of peasants, to improve their legal consciousness; We need to get the legal publicity and education as an important part of the government public service, to do in the interests of the people's government, for farmers rights protection consciousness propaganda, etc., so they can express their interests rationally.

\section{Conclusion}

Of course, rule of law is the connotation of modern civilized society, countryside government by law is the inevitable choice of rural social development, the problems that exist in the development, must be solved in the development. Countryside under the rule of law requires us to explore the way out of rural legal dilemma, first of all, strengthen the awareness of farmers' rights standard, then we will deepen reform of the system of rural democratic autonomy and modify the rural land contracting law again; finally strengthen the countryside the popularizing-law work, further improve the rural construction of the rule of law. All in all, the rule of law is to build a new socialist countryside is an important content, but strengthen the rule of law, to build a new socialist countryside is a solid system foundation, to go across a country under the rule of law construction. 


\section{References}

1. Haijun Zhang. discussion on how to strengthen the rule of law in ruralareas[J],agriculture in jilin,2012,(11).

2. Gaojie Mao. the social capital and the rural dispute resolution[D].Jilin: university of Jilin,2012 